\title{
SOUTH AFRICA'S EMERGING BLACK MIDDLE CLASS: A HARBINGER OF POLITICAL CHANGE?
}

\author{
ROBERT MATTES* \\ Department of Political Studies, University of Cape Town, Rondebosch, South Africa
}

\begin{abstract}
While South Africa has seen a significant increase in the post-apartheid period in the size of the Black middle class, the attitudinal consequences of indicators of the middle class, as of 2011, are inconsistent and modest in size. While they are no more likely to hold democratic values than other Black South Africans, they are more likely to want the government to secure 'higher-order' rather than basic survival needs. They are less likely to identify with the governing African National Congress and to turn out to vote. They are also less likely to 'voice' their concerns by contacting officials or joining in conventional or unconventional forms of collective action. Yet while intraracial class differences amongst Black people remain muted, intra-class racial differences amongst South Africa's middle class are still substantial. (C) 2015 The Authors. Journal of International Development published by John Wiley \& Sons Ltd.
\end{abstract}

Keywords: South Africa; survey research; attitudes; voting behaviour; political participation; middle class; democracy

\section{INTRODUCTION}

While definitions and estimates of its size differ, most analysts agree that the combination of a removal of apartheid restrictions and a series of public policy interventions such as affirmative action and Black economic empowerment has moved a sizable proportion of Black South Africans into the 'middle class'. At least since the classic statements of Seymour Martin Lipset (1959) and Barrington Moore (1966), comparative scholars of democratization have come to expect that the development and ultimate size of a country's middle class will assist the process of democratization because of its unique values, opinions and political behaviours. Within South Africa, some analysts expect the Black middle class to prioritize different public policy concerns (Netzhitenzhe, 2014) and to be

*Correspondence to: Robert Mattes, Department of Political Studies, University of Cape Town, Private Bag, Rondebosch 7701, South Africa

E-mail: robert.mattes@uct.ac.za

(C) 2015 The Authors. Journal of International Development published by John Wiley \& Sons Ltd.

This is an open access article under the terms of the Creative Commons Attribution-NonCommercial-NoDerivs License, which permits use and distribution in any medium, provided the original work is properly cited, the use is non-commercial and no modifications or adaptations are made. 
more critical of government performance and less supportive of the governing African National Congress (ANC) (Everatt, 2013, 2014). Others have argued the exact opposite, pointing out that the new Black middle class is dependent on clientelist government policies for their newfound well-being (Southall, 2012, 2014). Still, others have suggested that the rise of the Black middle class holds out the possibility of a new, cross-cutting cleavage that unites people of similar classes across the old apartheid divides of race and ethnicity (Feree, 2011; Everatt, 2013).

But while most analysts agree that a middle class is characterized by a relatively high level of income, specific occupations and specific levels of education, there is little agreement on precisely what it is about class that produces these effects. Is it differing material interests and relationships to the means of production (Marx \& Engels, 1992)? Is it the life chances and worldview imparted by certain types of occupations (Weber, 1958)? Is it the physiological security that it entails (Inglehart \& Welzel, 2005)? Or is it the cognitive skills produced by higher education (Dalton, 2013)? Or as in South Africa, where the Black middle class has rapidly developed very recently, is it simply the effect of a new generation socialized under democracy, with little memory of the ancient regime (Mannheim, 1972)?

In this paper, I review differing arguments about how the middle class is supposed to aid the endurance of democracy. I also review evidence about the growth of South Africa's middle class-variously defined. Based on the arguments of both comparative and South African scholars, I then develop a set of hypotheses that can be tested against available data from South African Afrobarometer surveys. I ask whether the members of the emerging Black middle class differ from other Black South Africans in terms of their electoral behaviours-particularly in their alignment vis-à-vis the dominant ruling ANC - and other forms of political participation, such as conventional or unconventional collective action. I also investigate whether they are more critical of government performance, place different policy demands on government and are more supportive of democracy. Finally, in contrast to the preceding focus on intra-racial class differences amongst Blacks, I end with a summary examination of intra-class racial differences amongst South Africa's middle class for each of the research questions mentioned earlier.

To anticipate my findings, there is little evidence that the Black middle class is anymore supporting of democracy than other Black South Africans, although there are signs that they are more likely to want the government to deliver 'higher-order' goods, such as free speech and a government that is accountable, rather than basic survival goods, such as food, water or shelter. They are less likely to identify with the governing ANC. And they are also more likely to 'exit' the democratic system rather than 'voice' their concerns by voting, contacting officials or joining with others to achieve political outcomes, whether through conventional or unconventional forms of collective action. Finally, while intraclass differences amongst Blacks are modest at best, intra-racial differences between middle-class Blacks, on one hand, and middle-class White, Coloured and Indian respondents, on the other, are still substantial. At least for now, the rise of the Black middle class does not portend a new non-racial dimension in South African politics.

\section{THE SOUTH AFRICAN CONTEXT}

From the time the ANC took political power in 1994, the transformation of the South African economy has been that party's overriding policy goal. While economic 
transformation, through the eyes of the ANC, has implied infrastructural development and economic growth, in general, it has also included the eradication of destitution and homelessness and the reduction of poverty. More importantly, economic transformation has also been seen to imply racial redistribution, which from the beginning has meantamongst other things - the creation of a new, Black middle class that would not only signal the accession of Black South Africans to economic power but would also act as a "patriotic bourgeoisie' and help drive the larger process of development.

As a governing party, ANC thinking about the process of general development has evolved over time, as articulated in a series of policy documents beginning with the short-lived expansionist Reconstruction and Development Plan, the sharp shift to the neo-liberal Growth, Employment and Redistribution plan, and its later evolution to the Accelerated Shared Growth Initiative. Since 2009, however, there has been far greater disagreement amongst economic policymakers, with key ministers calling for centralized planning and a 'developmental state' that would put the country on a 'new growth path'. Yet throughout the evolving policy rhetoric, there have been important constants to development policy in practice in the form of building community infrastructure (electricity, piped water and sewage); building houses and clinics; widening access to free education, medicine and basic health care; and expanding access to social welfare grants.

There have also been several important constants in government efforts to build a Black middle class by requiring affirmative action in public service hiring and by encouraging affirmative action in the private sector by setting demographic employment benchmarks, targets and timeframes in sector specific codes of practice and requiring successful bidders for state contracts to achieve minimum numeric scores in terms of 'Black economic empowerment'. Even before these codes were put into place, big businesses-perhaps anticipating the need to get out in front of the legislative curve-began to engineer a series of 'empowerment' deals that gave emerging Black business persons significant shares in many of the country's largest corporations.

Some analysts have worried that these forms of largesse would simply cement yet another strand into the already oversized ANC electoral coalition. Yet declining ANC vote totals in metropolitan areas in the recent 2014 national elections-especially in Johannesburg, Pretoria and Port Elizabeth where the vote share of the Democratic Alliance (DA), whose liberal politics and (mostly) neo-liberal economics have long tied to the White middle class, grew by double digits-have generated arguments that better off Black voters increasingly are less likely to acquiesce in the face of poor service delivery and corruption (Everatt, 2013, 2014).

\section{THE POLITICAL AND THEORETICAL IMPORTANCE OF THE MIDDLE CLASS}

Proceeding from the foundational conclusions of the classic studies of Seymour Martin Lipset (1959) ('the more well to do a nation, the greater the chances that it will sustain democracy') and Barrington Moore (1966) ('no bourgeoisie, no democracy'), a long line of studies have subsequently corroborated the empirical link between growth, wealth and democracy. And with very few exceptions (Acemoglu, Johnson, Robinson, Yard, 2008), most analysts accept that this link is in some way causal (for the most recent examples, see Przeworski, Alvarez, Cheibub, Limongi, 2000; Halperin, Siegle, Weinstein, 2005; Epstein et al., 2006; Norris, 2008; Teorell, 2010). While analysts have been far less 
clear on the possible reasons why factors associated with material wealth facilitate and/or sustain democracy, one important line of reasoning points to the role of the 'middle class'.

Two, often overlapping, tendencies characterize attempts to conceptualize and operationalise the middle class. The first approach defines it simply in terms of its 'middle-ness': that is, those people who either occupy the middle strata of the income distribution in a given country or a middle position between a lower class and an upper class (e.g. Seekings \& Nattrass, 2005, 2014; Bannerjee \& Duflo, 2008; and Lufeka, Mabila, Ben Aissa, 2011; Visagie \& Posel, 2011). The second sees the middle class as a discrete category with unique occupations and skills. And many scholars have pursued both approaches interchangeably. For example, Karl Marx famously saw the 'petty bourgeoisie' of professionals, small traders and shopkeepers as a functional buffer zone between the poor (proletariat) and the wealthy (capitalists) (Marx \& Engels, 1992). And according to Lipset (1959: 83), economic growth turns 'the shape of the class stratification structure so that it shifts from an elongated pyramid, with a large lower-class base, to a diamond with a growing middle class'. Yet it is not immediately clear why the sheer size of those occupying a middle point on an income distribution is relevant to democracy and democratic politics per se, unless there is something distinctive and unique to that group as a discrete category rather than as a middle space on a continuum. Thus, while Marx described the middle class as a buffer between the proletarians and the capitalists, its real relevance stemmed from the fact that while its members shared many of the same values and aspirations of the capitalist class, they did not own the means of production (Huntington, 1991; Marx \& Engels, 1992).

One causal path between the middle class and democracy may pass through the occupations that are widely associated with this stratum (Weber, 1958). Just as the skills learned in the factory produce more 'modern' values in developing countries (Inkeles, 1969), the skills and expanding life chances acquired in middle-class occupationsespecially business, professions, management and service sector-are said to transform values: drawing a regular salary, accumulating savings and pension funds and owning property give middle-class citizens a greater interest in the protection of private property and in gradual, rather than radical social, economic and political change (Lipset, 1959; Bannerjee \& Duflo, 2008). However, a different argument traces the causal path between the middle-class and pro-democratic values not through occupation per se but through higher levels of education that stimulate cognitive development and promote civic values (Lipset, 1959; Huntington, 1961; Dalton, 2013). In the first instance, a sizable middle class provides a critical mass of people who possess the organizational, financial, managerial and research skills to staff the legislatures, ministries, departments and agencies that make democracy work (see Mattes and Mozaffar, 2011). In the second instance, a sizable middle class also provides a mass of citizens who make democracy work by supporting and participating in the institutions of democracy (Lipset, 1959).

A third argument sees both occupation and education as mere markers of a much more important characteristic of the middle class: that is, sharply lower levels of scarcity and physiological insecurity. Based on the logic of Abraham Maslow's (1954) hierarchy of needs, Ronald Inglehart (Inglehart \& Abramson, 1995: Inglehart \& Welzel, 2005) argues that people value that which is in least supply (the 'scarcity hypothesis'). Thus, membership in the middle class is less a marker for education as it is of people who experience relative abundance and physiological security: that is, people who have solved 'basic needs' (e.g. food, water and shelter) and 'middle-order needs' (e.g. steady employment, physical safety, health care and old age pensions) and thus come to value 
'higher-order needs' such as self-expression, democracy, gender rights and environmental protection.

However, Inglehart further specifies this argument in a way that has special relevance for South Africa. While fundamental political values are determined by scarcity or abundance, values are formed and solidify during the period of late adolescence (the 'socialization hypothesis'). Thus, the key question in a developing society is not so much the current size of the adult middle class, but rather the number of people who grew up under conditions of relative security and affluence. In South Africa, trade union and Communist Party members often describe the newly wealthy former leaders of the liberation struggle-figures such as Trevor Manuel, Cyril Ramaphosa, Tokyo Sexhwale and Mamphela Ramphele_as 'sell outs' and 'class traitors'. ${ }^{1}$ However, Inglehart's theory predicts that these individuals would have retained the same basic values and policy goals that they formed as young militants and revolutionaries. A values gap would emerge only between Manuel et al., on one hand, and their children, on the other: that is, the so-called 'born free' generation who have grown-up in middle-class households and attend relatively privileged schools and universities.

While few South African scholars have explicitly addressed the issue of the new Black middle class in terms of the survival of democracy, some have begun to focus on its implications for the quality of democracy and electoral politics in that country. Echoing Maslow, Joel Netzhitenzhe (2014: 25) has argued that the marginal declines in ANC victory margins across the country's metropolitan areas in the recent 2014 election 'represents [sic] the voice of a middle strata that are dissatisfied with specific issues'.

Though their rise and sustenance depend directly or indirectly on government policies, they do not rely on state largesse in the form of access to water, electricity, social grans and other such basic services. And so ... other issues such as probity, ethics, accountability, decency in the conduct of politics ... start to assume prominence in their voting behaviour or even electoral participation.

At the same time, the logic of Albert O. Hirschmann's (1970) argument in Exit, Voice and Loyalty might predict that such dissatisfaction would, in fact, lead the middle class to 'exit' the formal democratic process rather than 'voicing' their displeasure through voting or through either individual or collective action and instead utilize their skills and ambitions to achieve their goals outside of the political arena. Yet not all analysts agree that that the Black middle class will necessarily be hostile to the governing party. Roger Southall (2012, 2014), for example, argues that successive ANC governments' use of policy tools like affirmative action, Black economic empowerment and state development contracts has drawn the new Black middle class into a 'state-party-class coalition' with the ANC.

\footnotetext{
${ }^{1}$ Manuel began his political career as a student activist in Cape Town, member of the South African Communist Party, and one of the leaders of the internal resistance movement, the United Democratic Front. After entering government in 1995, he became Minister of Treasury and presided over the government's policy switch to a neo-liberal structural reform programme. Ramaphosa was originally the head of the National Mineworkers Union and then became the Secretary General of the African National Congress. Snubbed of the position of Deputy President in 1994, he left and entered the business world and started Shanduka Group, becoming one of the most successful businessmen men in South Africa with a net worth, according to Forbes, of $\$ 700$ million. Sexhwale was a senior figure in the South African Communist Party and close confidante of party leader Chris Hani. He was later Premier of Gauteng Province and after leaving politics also became one of the country's wealthiest businesspersons as Chairman of mining conglomerate Mvelapanda Group. Ramphele was an activist in the Black Consciousness Movement and a close confidante of its leader Steven Biko. After working in civil society and academia, she left the country to become a Senior Vice President of the World Bank. Since then, she has been a Director of several different companies and is listed by Forbes as one of the richest women in Africa.
} 


\section{SOUTH AFRICAN TRENDS IN WELL-BEING}

Regardless of the policy shifts away from Keynes to Friedman and now apparently back again, the constants of actual delivery have resulted in major infrastructural achievements. Access to basic sanitation increased from 50 per cent of the population in 1995, the year after the country's first non-racial election, to 83 per cent by 2012. Access to a basic level of piped water went from 60 to 95 per cent of all households over the same period, and the proportion with access to electricity went from 50 to 86 per cent by 2014 (Presidency, Republic of South Africa, 2014: 71-72). Approximately 3.7 million subsidized houses have been built, and the proportion of people in formal housing increased from 64 per cent in 1996 to 78 per cent in 2011 (Presidency, Republic of South Africa, 2014: 67-68). In terms of health care, 1500 new clinics and 18 public hospitals were built, and half of the existing 400 public hospitals were renovated. Primary healthcare services are now provided free of charge to all people, and the proportion of people who use public clinics jumped from 45 per cent in 2004 to 60 per cent in 2012 (Presidency, Republic of South Africa, 2014: 54, 105). In terms of education, the ANC government built, by 2012, 2700 new schools and 84500 new classrooms. Seventy-eight per cent of students received fee waivers, resulting in an increase in gross secondary school enrolment from 51 per cent in 1993 to 89 per cent by 2012, and nine million children received free lunches every day at school (Presidency, Republic of South Africa, 2014: 47-48, 103). Finally, the number of people receiving a social grant grew from 2.7 in 1994 to 16 million in 2013 (mostly via the child support grant), and South Africa now spends 3.4 per cent of gross domestic product on these and similar grants (Presidency, Republic of South Africa, 2014: 45).

But the vast achievements in building infrastructure and widening access to public services have resulted in only modest improvements in well-being. While the percentage of people living under various income poverty lines has fallen, real household incomes have grown only in the top quintile and bottom decile, with trends in the bottom 10th wholly attributable to the effect of social grants (Bhorat \& Van Der Westhuizen, 2010; Leibbrandt, Woolard, Finn, Argent, 2010; Presidency, Republic of South Africa, 2014: 45-46). Indeed, unemployment increased from 20 per cent in 1994 to 25 per cent in 2013 by the official measure and from 32 to 36 per cent by the expanded definition (Donnelly, 2013).

With the contending effects of decreasing employment and increasing social grants, others qualify of life indicators have shown little overtime movement. Afrobarometer has developed a valid and reliable module that measures the extent to which people 'go without' a basket of basic necessities, including food, clean water, necessary medical care and fuel, for home heating or cooking, as well as a cash income (Mattes 2008) (for wording see Appendix). According to Afrobarometer South Africa surveys conducted between 2002 and 2011, there was a real decrease in the percentages of Black respondents that report frequent shortages of food. This drop has probably been concentrated amongst households that receive child support grants, as StatsSA surveys have found an even larger drop in reported hunger in households with children (Van der Berg, Louw, du Toit, 2007; Van Der Berg, 2010). All other indicators, however, show trendless variation over that same period (Figure 1). In corroboration of these data, Kane-Berman (2014) has cited government surveys that show that while almost 86 per cent are entitled to receive a basic minimum of free water each month, one-fifth of households say they have gone at least two consecutive days or longer without water (Kane-Berman, 2014). Thus, while the 
increasing size of the South African welfare state has managed to counter the effects of increasing unemployment, its limitations have meant that overall levels of lived poverty have not diminished.

\section{ESTIMATES OF SOUTH AFRICA'S EMERGING BLACK MIDDLE CLASS}

The clear trend in personal income across the first two decades of South African democracy has been one of stagnation across the bottom four-fifths of the population (helped in the bottom 10th only by social grants), but growth amongst the top fifth (Whiteford \& Van Seventer, 1999; Budlender, 2000; Bhorat \& Van Der Westhuizen, 2010; Leibbrandt et al., 2010). It is this growth that has generated the rapid expansion of a middle class amongst Black South Africans. While the trends reviewed in the previous section were driven largely by state investments in infrastructure construction and social grants, the growth of the middle class has been driven by legislative changes regarding employment equity (affirmative action) and Black economic empowerment.

Estimates of trends and the absolute size of the Black middle class vary depending on whether one examines income, class or self-described class identities. The most systematic longitudinal attempt comes from a recent study of annual household surveys from 1993 to 2012 conducted by researchers at the University of Stellenbosch (Kotze et al., 2013). They found - using an income standard of R25000 per annum (in 2000 prices, or US\$3250)_ that the absolute size of South Africa's Black middle class grew from 350000 in 1993 to almost 3 million by 2012. It is of interest that Southall (2012), using a strictly occupational approach, has come to roughly similar estimates, finding an increase in the number of Black South Africans employed in non-manual, white collar occupations growing from 840000 in 1991 to 3.8 million in 2011. In relative terms, this represents a modest, though still significant shift from 1 to 7 per cent of the Black population. Perhaps more importantly, Kotze et al. (2013) calculate that the Black share of the country's middle class (so defined) jumped from 11 to 41 per cent. This implies important shifts in a range of social phenomena from the nature and preferences of those able to purchase goods and services like automobiles, houses and insurance or able to send their children to previously White public and private schools, as well as the composition of the country's affluent suburbs. Blacks, for example, now take 53 per cent of all first degrees awarded by the country's universities (Kane-Berman, 2014) and outnumber Whites in terms of suburban home purchases (Presidency, Republic of South Africa, 2014: 68).

Researchers from the Stellenbosch group have also calculated an alternative, multidimensional 'capabilities' measure consisting of employment; literacy; access to services such as clean water, sanitation and electricity; and ownership of assets such as stove, refrigerator, radio and television (McAravey, Burger, Van der Berg, 2013). They then reset the per capita income threshold so that the overall proportion defined as middle class in 1993 would be the same as that estimated by the capabilities approach (12 per cent). However, because these two sets are not composed of the same individuals, the proportion of Blacks that qualify as middle class (so defined) in 1993, using both the income and capabilities measures, was just 4 per cent but increased to 12 per cent in 2008 (and the Black share of the middle class expanded from 17 to 45 per cent). However, if one uses only the capabilities approach, the percentage of middle-class Blacks began at 12 per cent and increased to 27 per cent (increasing from 32 to 60 per cent of that group) (McAravey et al., 2013). 


\section{DOES THE NEW BLACK MIDDLE CLASS DIFFER POLITICALLY FROM OTHER BLACK SOUTH AFRICANS?}

Thus, whether one uses an income, occupational or capabilities based approach, or some combination thereof, there appears to have been an exponential expansion of the Black middle class over the past 20 years, although its precise size and relative growth is far from clear. Depending on the measure employed, the percentage of Black South Africans who might be classified as middle class ranges anywhere from 8 to 27 per cent. And in terms of its overall economic impact, Black South Africans now comprise anywhere from 40 to 60 per cent of South Africa's middle class.

But the political impact of this expansion depends greatly on whether the values, preferences, evaluations and behaviours of the Black middle class actually differ in any important ways from other Black South Africans. Unfortunately, none of the large household surveys collected by the South African state, universities or market research firms contain the necessary questions about political attitudes and behaviours that would allow us to examine these arguments. The most recent South African World Values Survey (2013) is not yet available to the wider scholarly community, and the previous one (2006) would be too old for our purposes given the rapid and recent rise of the Black middle class.

We do, however, have access to the 2011 South Africa Afrobarometer survey. It comprises personal face-to-face interviews, in the language of the respondent's choice, with a random, representative, area probability cluster sample of 2400 South Africans aged 18 years and over. The sampling frame consisted of census enumerator areas and was stratified by province, rural-urban differences and dominant racial group. Four interviews each were conducted in 600 enumerator areas that were selected from each stratum with probability proportionate to population size. The dataset contains responses to a wealth of questions about a range of attitudes on democracy, political institutions, political parties and individual political participation that could serve as dependant variables in tests of the political impacts of class.

In terms of measures of class - the independent variable-our theoretical interest is in identifying people who do not merely occupy the middle of the income scale between the extremes of the poor and the rich, but rather who through what they do, their cognitive skills or their freedom from physiological insecurity may possess a distinctive set of interests or values that are conducive to democracy. Thus, in order to test the occupational argument, I would want to be able to identify people in households where the head of household is fully employed and either does not work for others (business people, selfemployed professionals or commercial farmers) or works for others within the middle hierarchies of professional and service sector firms, or public and corporate bureaucracies. In order to test the cognitive argument, I would want to identify those people who either have specialized post-secondary educational training or who attended university. And to test the physiological insecurity argument, I would want to identify those people who have access to key services and are free from want of basic necessities.

However, while earlier Afrobarometer surveys asked respondents about their own occupation (though not head of household for respondents who are unemployed, housewives or dependent students), the question was dropped after 2006. ${ }^{2}$ However,

\footnotetext{
${ }^{2}$ Using comparable earlier surveys carried out by the Institute for Democracy in South Africa and Afrobarometer surveys from 2000 to 2006, the results indicate an increase in the proportion of Black adults with a business or professional occupation from 7 per cent in 1997 to 13 per cent in 2006.
} 


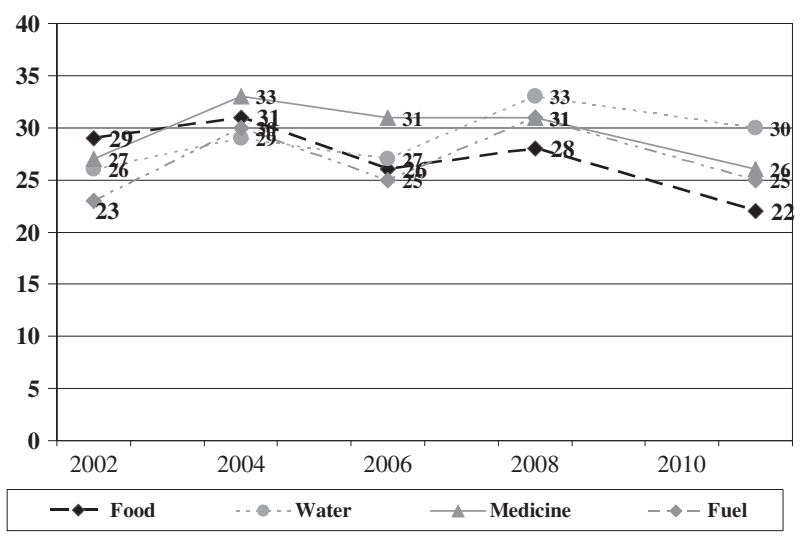

Figure 1. Indicators of lived poverty over time (Black South Africans)

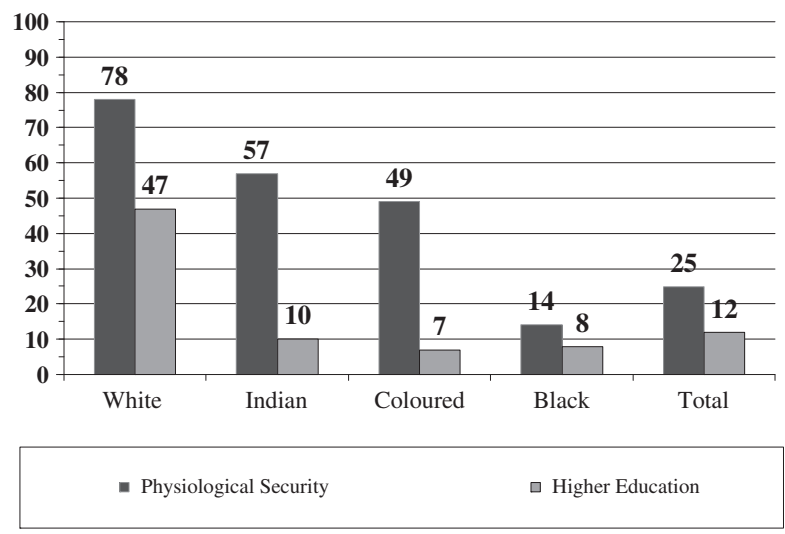

Figure 2. Middle class indicators, 2011

Afrobarometer has continued to ask a standard measure of educational attainment (measured as the highest level of schooling attained). ${ }^{3}$ As of 2011, just 8 per cent of all adult Black respondents told Afrobarometer interviewers that they had any kind of training or education at a tertiary institution. In contrast, almost half of adult White respondents (47 per cent) had similar levels of education, although the proportions of Indian (10 per cent) and Coloured (7 per cent) respondents were roughly equivalent to Black South Africans (Figure 2).

Finally, the Afrobarometer module on lived poverty discussed previously provides at least one element of a potential measure of physiological security. But instead of experiences of shortages of basic necessities, this measure would focus instead on those respondents who say they 'never' go without food, clean water, home cooking fuel or necessary medical care. In the 2011 survey, 30 per cent of Black respondents said they 'never' went without any of these four basic necessities. ${ }^{4}$ Yet many of these respondents

\footnotetext{
${ }^{3}$ While the Institute for Democracy in South Africa/Afrobarometer surveys track a consistent over time increase in the proportion of adult Black South Africans who have completed high school (from 18 per cent in 1994 to 26 per cent in 2011), the data show trendless variation (between 9 and 15 per cent) in the proportion of adults that say they have any tertiary education or have completed an undergraduate university education.

${ }^{4}$ The percentage of Black South Africans who tell Afrobarometer fieldworkers they 'never' go without enough food, clean water, home fuel for cooking or heating or necessary medical treatment has varied since 2000 between 28 and 26 per cent, but the data reveal no upward trend.
} 


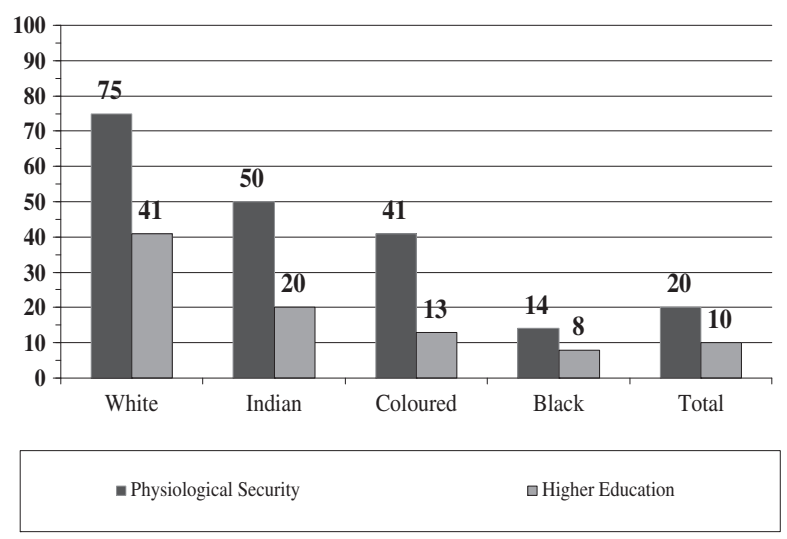

Figure 3. Born free middle class indicators, 2011

may still lead relatively precarious lives, obtaining these necessities through basic survival strategies, rather than through access to modern municipal services and amenities, especially those who live in rural areas. Thus, we also utilize two recently added question items on whether respondents have piped water or flush toilets within the household. As of 2011, just one-third of all Black respondents report having piped water (33 per cent) or a flush toilet (31 per cent) inside their household (as opposed to and within a communal compound or a facility outside the compound). Putting all of this together, the proportion of Black respondents who never go without basic necessities and have piped water and a flush toilet inside their house, comes to just 14 per cent. In contrast, the number of White adult respondents (78 per cent) who fit the same criteria is seven times higher, and the proportion of Coloured (49 per cent) and Indian (57 per cent) respondents is three to four times as high. Overall, one-in-four (25 per cent) South Africans could be regarded as physiologically secure in 2011 (Figure 2). ${ }^{5}$

Finally, in order to operationalize the Inglehart conceptualization that combines socialization and physiological security, I estimate the size of the young middle class, that is, those South Africans who are likely to have passed through their formative years (14-22) since the passage of the 1996 Constitution (known in South Africa as the 'born frees' and as of 2011, aged 18-34 years) under conditions of physiological security or having attained at least some post-secondary schooling. This yields an estimate of 7 per cent (physiological security) and 8 per cent (higher education) of all young Black respondents, the same proportion as of the overall Black adult population. The figures for younger White, Indian and Coloured respondents are also very similar to that of the overall sample (Figure 3).

\section{POLITICAL CONSEQUENCES}

We now turn to the key question: to the extent that there is now an identifiable, though still relatively small Black middle class in South Africa, what consequences, if any, does this portend for the process of democratic consolidation in that country, either attitudinally

\footnotetext{
${ }^{5}$ Seekings and Nattrass (2014) do not provide a racial breakdown of their estimates of South Africa's changing class structure between 1993 and 2008, but they claim that the share of all households in 2008 with a head of household employed in business, professional and management, self-employed and semi-professional sectors was 20 per cent (up from 17 per cent in 1993).
} 
or behaviourally? Using the most recently available Afrobarometer data from 2011, I create a measure of physiological security (which takes the value of 1 if respondents 'never' go without the four basic necessities and have piped water and a flush toilet in the household, and 0 if otherwise) and a measure of cognitive skills (which takes the value of 1 if respondents have any kind of post-secondary training or at least some university education, and 0 if otherwise). And because it is possible that class reflects the joint effects of both (in)security and cognitive skills, I also create a dummy variable that measures the interaction of these two measures: it equals 1 if a respondent was both physiologically secure and had some higher education. Finally, in order to test the socializing effect of having grown-up secure and well-educated, I create an indicator that takes the value of 1 if the respondent is aged 18-34 and is physiologically secure and has any higher education.

I begin by examining a few key bivariate correlations of physiological security and postsecondary education amongst Black South Africans (Table 1). What this reveals, first of all, is that while the link between post-secondary education and physiological security is statistically significant and positive, it is rather modest (Pearson's $r=0.167$ ). In other words, these measures appear to tap relatively unique aspects of what one might consider middle class. The correlations also suggest that those Black South Africans who are relatively secure in their enjoyment of basic physiological necessities and who have a post-secondary education are both more likely to be interested in politics and discuss politics with family and friends (cognitive engagement) and more likely to listen to radio and television news or read newspapers on a frequent basis (news media use). At the same time, they are both less likely to live in rural areas (far more so for physiological security). Perhaps surprisingly, neither measure registers any significant differences between men and women or between the born frees and the older respondents.

The rest of the analysis proceeds in two parts. I first employ a series of multiple regression models to test whether the members of the Black middle class (as indicated by either physiological security, higher education or combination of the two) or the younger members of the middle class are indeed more likely than other Black South Africans to value democracy, prefer different types of policy outcomes, evaluate government performance more critically, withdraw their support from the governing ANC or withdraw from democratic politics. In order to ensure that we are tapping the effects of class per se, and not its other correlates, I control for the simultaneous effects

Table 1. Correlates of class (Black South Africans)

\begin{tabular}{lccc}
\hline & Physiological security & Higher education & $\begin{array}{c}\text { Physiologically secure } \\
\text { and higher education }\end{array}$ \\
\hline Physiological security & - & $0.167 * * *$ & $0.412^{* * *}$ \\
Higher education & $0.167 * * *$ & - & $0.561^{* * *}$ \\
News media use & $0.222^{* * *}$ & $0.292^{* * *}$ & $0.156^{* * *}$ \\
Cognitive engagement & $0.101^{* * *}$ & $0.108^{* * *}$ & $0.071^{* *}$ \\
Rural & $-0.287^{* * *}$ & $-0.159^{* * *}$ & $-0.114^{* * *}$ \\
Women & 0.023 & $-0.042^{*}$ & -0.033 \\
Born free & 0.012 & $-0.060^{* *}$ & 0.012 \\
\hline
\end{tabular}

Cells display Pearson's $r$ correlations and levels of statistical significance:

$n=1829$

$* p<=0.05$,

$* * p<=0.01$,

$* * * p<=0.001$. 
of gender, rural/urban status, age, education, cognitive engagement and news media use. Where the key comparisons in this section are between middle-class Blacks and their poorer, less educated compatriots, in the second and final portions of the analysis, I focus on all respondents who are physiologically secure and better educated to test whether racial differences are still significant amongst middle-class South Africans.

In the first series of models, I test the Lipset argument that middle-class citizens will have a greater stake in and thus be more supportive of democracy than their working class, agrarian or unemployed fellow citizens. More specifically, I employ four different measures of democratic values. Second, I use the well-developed index of Demand for Democracy (a four item average index that measures the extent to which respondents prefer democracy and reject one party rule, military rule and presidential dictatorship) (Bratton, Mattes and Gyimah-Boadi 2005). And beyond support for a nominal regime type, I create a scale that taps Demand for Democratic Institutions (a six-item average scale that assesses whether people support regular elections, presidential term limits, parliamentary control of the legislative process, parliamentary oversight of the executive, opposition party criticism of government and investigative news media). Finally, I use two single item questions that measure support for two key civil liberties: Support for Free News Media and Support for Free Association (for full wording and coding of each of questions, and estimates of scale validity and reliability, see the Appendix). While welleducated Black people score significantly higher on each of these scales, the size of the impact is very modest: one-fifth of a point on a five-point scale (0-4) (Table 2). Moreover, there is no indication that physiologically secure Blacks (those who never go without basic necessities and have access to piped water and electricity in the household), those

Table 2. Consequences of class for democratic values (Black South Africans)

\begin{tabular}{|c|c|c|c|c|}
\hline & $\begin{array}{l}\text { Demand for } \\
\text { Democracy } \\
\quad(0-4)\end{array}$ & $\begin{array}{c}\text { Demand for } \\
\text { Democratic Institutions } \\
(0-4)\end{array}$ & $\begin{array}{l}\text { Support for Free } \\
\text { News Media } \\
(0-4)\end{array}$ & $\begin{array}{l}\text { Support for Free } \\
\text { Association } \\
(0-4)\end{array}$ \\
\hline Constant & 2.956 & 2.444 & 2.308 & 2.710 \\
\hline $\begin{array}{l}\text { Physiological } \\
\text { security }\end{array}$ & 0.059 & 0.034 & 0.029 & 0.139 \\
\hline Higher education & $0.206^{*}$ & $0.219^{* *}$ & 0.192 & 0.253 \\
\hline $\begin{array}{l}\text { Secure* higher } \\
\text { education }\end{array}$ & -0.091 & 0.166 & -0.270 & 0.110 \\
\hline Born free & -0.057 & -0.011 & -0.093 & 0.017 \\
\hline $\begin{array}{l}\text { Born free* secure* } \\
\text { higher education }\end{array}$ & -0.138 & -0.298 & 0.106 & -0.303 \\
\hline Rural & -0.046 & $0.091 *$ & 0.038 & -0.080 \\
\hline Women & -0.042 & 0.061 & 0.078 & -0.003 \\
\hline News media use & -0.014 & -0.021 & -0.013 & -0.015 \\
\hline $\begin{array}{l}\text { Cognitive } \\
\text { engagement }\end{array}$ & 0.008 & $0.066^{* *}$ & 0.022 & $-0.146 * * *$ \\
\hline Multiple $r$ & 0.078 & 0.126 & 0.056 & 0.112 \\
\hline Adjusted $R^{2}$ & 0.001 & 0.011 & 0.003 & 0.008 \\
\hline$n$ & 1829 & 1829 & 1829 & 1829 \\
\hline
\end{tabular}

Cells display unstandardized ordinary least squares regression coefficients and levels of statistical significance:

$* p<=0.05$,

$* * p<=0.01$,

$* * * p<=0.001$. 
socialized since the end of apartheid, nor any respondent tapped by the middle-class interaction terms, are more likely to hold democratic values than other Black respondents.

Next, I explore whether materially better-off Black South Africans prioritize different sets of issues and problems for government action. Afrobarometer asks respondents to state the three most important issues or problems that they think the government should address. Following the work of Inglehart (Inglehart \& Abramson, 1995; Inglehart \& Welzel, 2005), I group the responses to this open-ended question into a series of dummy variables indicating basic physiological priorities (e.g. poverty, hunger, disease, water and housing); economic middle-order priorities (i.e. employment, inflation and inequality); security middle-order priorities (i.e. crime, security and violence); and higher-order priorities (i.e. corruption, environment, rights and liberties and democracy). Because the new response categories are coded $0-1$, I use logistic regression for these four models (Table 3 ).

The results show that well-being does, consistent with the Inglehart theory, make Black respondents more likely to prioritize 'higher-order' needs, such as corruption, speech, civil liberties or democracy, and less likely to prioritize basic physiological priorities as goals of government action. Those who are both secure and have higher education are also less likely to prioritize issues around crime or law and order. However, there are no significant linkages between well-being or higher education and any other priority area. Young Blacks are less likely to prioritize basic survival needs (although young middle-class Blacks are more likely) and are more likely to emphasize issues around economic growth and economic management than are other Black respondents. Thus, the probability that Black South Africans want the government to focus on securing basic needs, physical security or

Table 3. Consequences of class for issue priorities (Black South Africans)

\begin{tabular}{|c|c|c|c|c|}
\hline & $\begin{array}{c}\text { Basic } \\
\text { physiological } \\
\text { priorities }\end{array}$ & $\begin{array}{c}\text { Economic } \\
\text { middle-order } \\
\text { priorities }\end{array}$ & $\begin{array}{c}\text { Security } \\
\text { middle-order } \\
\text { priorities }\end{array}$ & $\begin{array}{l}\text { Higher-order } \\
\text { priorities }\end{array}$ \\
\hline Constant & 1.957 & 1.600 & -1.383 & -1.748 \\
\hline $\begin{array}{l}\text { Physiological } \\
\text { security }\end{array}$ & $-0.447 * *(0.639)$ & $-0.029(0.972)$ & $0.268(1.308)$ & $0.591 * * *(1.805)$ \\
\hline $\begin{array}{l}\text { Higher } \\
\text { education }\end{array}$ & $-0.106(0.900)$ & $0.418(1.518)$ & $0.103(1.109)$ & $-0.544(0.580)$ \\
\hline $\begin{array}{l}\text { Secure* higher } \\
\text { education }\end{array}$ & $-0.413(0.662)$ & $-0.444(0.641)$ & $-1.847 *(0.158)$ & $0.718(2.050)$ \\
\hline Born free & $-0.303 *(0.738)$ & $0.490 * * *(1.632)$ & $0.176(1.193)$ & $-0.139(0.870)$ \\
\hline $\begin{array}{l}\text { Born free* } \\
\text { secure* higher } \\
\text { education }\end{array}$ & $1.490 *(4.437)$ & $-0.352(0.704)$ & $1.545(4.688)$ & $-0.563(0.569)$ \\
\hline Rural & $0.128(1.136)$ & $0.294(1.328)$ & $-0.482 * * *(0.618)$ & $-0.254 *(0.775)$ \\
\hline Women & $0.404 * * *(1.498)$ & $-0.106(0.899)$ & $-0.094(0.910)$ & $-0.364 * *(0.695)$ \\
\hline News media use & $-0.142 *(0.868)$ & $-0.068(0.935)$ & $0.192 * * *(1.211)$ & $0.349 * * *(1.417)$ \\
\hline $\begin{array}{l}\text { Cognitive } \\
\text { engagement }\end{array}$ & $-0.094(0.911)$ & $0.182 *(1.200)$ & $-0.004(0.996)$ & $-0.137 *(0.872)$ \\
\hline Nagelkerke $R^{2}$ & 0.042 & 0.023 & 0.050 & 0.080 \\
\hline$n$ & 1829 & 1829 & 1829 & 1829 \\
\hline
\end{tabular}

Cells display unstandardized logistic regression coefficients; levels of statistical significance:

$* p<=0.05$,

$* * p<=0.01$,

$* * * p<=0.001 ;$ and odds ratio. 
higher-order needs is related to their levels of well-being and socialization experiences. But there are no linkages between class-related factors and the likelihood that people cite issues around growth, inflation, unemployment or inequality (the issues that are most frequently cited by Black respondents). At least amongst Black respondents, there seems to be a cross-class consensus around the need for the government to complement the impressive welfare state that it has created with economic growth, expansion of employment and keeping prices in check. Job creation, for example, has been routinely prioritized by anywhere from 60 to 70 per cent of respondents in every survey that has asked the questions since 1994.

While middle-class Blacks are more likely to prioritize issues of corruption, governance and democracy as priorities for government action and less likely to want government to focus on securing basic needs, does this mean that they are more critical of government performance? To test this, I construct four separate measures of public evaluations of different aspects of government performance. The first three tap the extent to which respondents think the government is doing well or badly in 'handling' issues of macro-economic management evaluations (economic management, job creation, controlling inflation or narrowing inequality); service delivery evaluations (delivering houses, water, health care, electricity and social grants); or controlling crime and corruption evaluations (fighting crime and reducing official corruption). I also use a single item to measure presidential performance evaluations that asks people how well President Jacob Zuma performed his job over the previous 12 months. The results demonstrate that, amongst Black respondents, neither physiological well-being nor higher education leads to more negative performance assessment, and in one case (physiological security and service delivery), the relationship is significant and positive. And younger Black respondents, though not younger middle-class respondents, consistently offer more positive evaluations across all three policy performance dimensions (Table 4).

I next test the electoral arguments advanced by Netzhitenzhe (2014) (who has argued that the middle class have begun to desert the ANC) and Southall (2011) (who argues that it is becoming more supportive, relative to other voters). I examine whether the physiologically secure, those with higher education, or the young middle class differs from other Black respondents in the extent of ANC partisanship (whether or not they say they 'feel close' to the ANC), DA partisanship (whether or not they say they 'feel close' to the liberal DA), voter turnout (whether the respondent voted in the 2009 election) and $A N C$ vote and DA vote (whether those who said they would vote in the next election would vote for the ANC or the DA 'if an election were held tomorrow') (actual survey question and response wordings are listed in the Appendix). Because each of these questions items has a dichotomous response choice, I use logistic regression for these items (Table 5).

In line with the arguments of Netzhitenzhe (2014), Black voters who are physiologically secure and who have been socialized since the end of apartheid (the 'born frees') are both less likely to identify with the ANC. Conversely, while just 1.2 per cent of all Black respondents in the 2011 survey said they 'felt close' to the DA (as opposed to 55 per cent for the ANC), those respondents are disproportionately likely to have post-secondary education. In terms of voter turnout, younger Black voters are less likely to say they voted in the previous (2009) election, even after removing those respondents who were actually too young to have voted. Much of this, however, is related to the standard cross-national finding of the negative relationship between youth 
Table 4. Consequences of class: government performance evaluations (Black South Africans)

\begin{tabular}{lcccc}
\hline & $\begin{array}{c}\text { Macro-economic } \\
\text { management } \\
(0-4)\end{array}$ & $\begin{array}{c}\text { Service delivery } \\
(0-4)\end{array}$ & $\begin{array}{c}\text { Crime and } \\
\text { corruption }(0-4)\end{array}$ & $\begin{array}{c}\text { Presidential } \\
\text { performance } \\
(0-4)\end{array}$ \\
\hline Constant & 0.623 & 1.404 & 1.043 & 2.135 \\
Physiological security & 0.063 & $0.155^{*}$ & 0.046 & 0.125 \\
Higher education & 0.112 & 0.079 & 0.134 & 0.087 \\
Secure* higher education & 0.010 & 0.145 & -0.025 & -0.176 \\
Born free & $0.220^{* * *}$ & $0.114^{* *}$ & $0.177^{* *}$ & 0.064 \\
Born free* secure* higher & -0.022 & -0.301 & 0.086 & 0.191 \\
education & $0.268^{* * *}$ & 0.043 & $0.347^{* * *}$ & $0.186^{* * *}$ \\
Rural & -0.017 & 0.020 & 0.004 & -0.013 \\
Women & $0.059^{* *}$ & $0.084^{* * *}$ & 0.035 & 0.003 \\
News media use & $0.176^{* * *}$ & $0.099^{* * *}$ & $0.106 * * *$ & $0.183^{* * *}$ \\
Cognitive engagement & 0.250 & 0.215 & 0.178 & 0.158 \\
Multiple $r$ & 0.058 & 0.042 & 0.027 & 0.020 \\
Adjusted $R^{2}$ & 1829 & 1829 & 1829 & 1829 \\
$n$ & & & & \\
\hline
\end{tabular}

Cells display unstandardized ordinary least squares regression coefficients and levels of statistical significance: $* p<=0.05$,

$* * p<=0.01$,

$* * * p<=0.001$.

and electoral participation (Norris, 2003). At the same time, Black respondents with higher education are less likely to say they voted, a finding that stands in sharp contrast to the standard relationships found in comparative studies (Norris, 2003). Finally, younger Black respondents are significantly less likely to say they would vote for the ANC 'if an election were held tomorrow'. And while just 4 per cent of all Black respondents said they would vote for the DA (compared with 90 per cent for the ANC), those few respondents are substantially more likely to come from the Black middle class. Both physiologically secure respondents and those with higher education are significantly more likely to vote DA, as are younger Black voters. In sharp contrast to the Southall (2012) argument, there is no evidence in these data that Black economic empowerment or affirmative action policies are drawing the Black middle class into even greater support for the ANC (Southall, 2012).

Finally, I examine whether there is any evidence that the new Black middle class is 'exiting' from the democratic process (Hirschmann, 1970). I develop five different indices of participation beyond voter turnout. I create average scales of campaigning (the extent to which respondents attended a campaign rally, persuaded others how to vote or worked for a party or candidate in the 2009 election campaign); joining (the extent to which respondents are active member of religious or civic associations); communing (how frequently they attend community meetings or join political action groups); contacting (how frequently they contact elected representative, party officials or government officials); and protesting (how frequently people attend protests and take part in political violence).

The results show that Black respondents who have secured their basic necessities are indeed less likely to take part in election campaign activities and to contact elected officials between elections and substantially less likely to take part in forms of collective action such as communing and protesting, than other Black South Africans. At the same time, Black respondents with higher education are more likely to take 


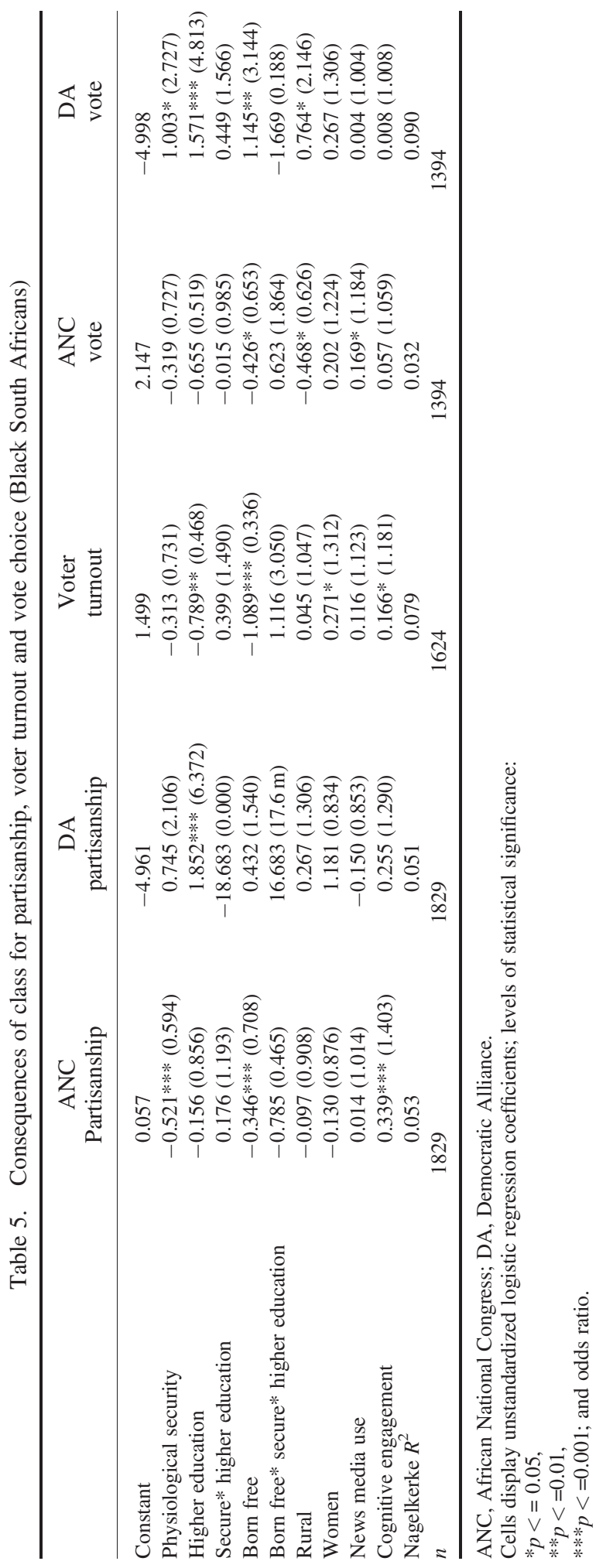


part in some of these activities (campaign politics and contacting officials between elections). While the born free generation is also less likely to join community organizations, contact officials or take part in community affairs, this appears to be largely a result of the ageing process rather than class because-with one exception - the interaction of youth with well-being and higher education has no significant impacts (Table 6).

\section{A NON-RACIAL MIDDLE CLASS?}

In the preceding analysis, the key comparison was between middle-class Blacks and their poorer, less educated compatriots. It revealed that physiological security and higher education often lead to differing attitudes and behaviours, although the effects are far from consistent and often quite modest in size. But the democratic promise of the emergence of a Black middle class has been seen to arise not only from the possibility that it might generate a materialist cleavage amongst Black South Africans-and thus, amongst other things, reduce the extent to which Blacks vote as a block-but also from the possibility that it may create a new dimension of political cooperation and consensus amongst middle-class voters, regardless of how they or their parents used to be categorized by the apartheid system.

Thus, in the final portion of this analysis, I focus only on those respondents $(n=731)$ who are either physiologically secure or better educated to test whether racial differences are still significant amongst the increasingly pan-racial middle class (of the 731 respondents, in the weighted sample, 47 per cent were Black, 31 per cent were White, 16 per cent were Coloured, and 6 per cent were Indian). I then re-run each of the analyses discussed earlier amongst this group of respondents with race indicated by a series of

Table 6. Consequences of class: political participation (Black South Africans)

\begin{tabular}{|c|c|c|c|c|c|}
\hline & $\begin{array}{c}\text { Campaigning } \\
(0-4)\end{array}$ & $\begin{array}{c}\text { Joining } \\
(0-4)\end{array}$ & $\begin{array}{c}\text { Communing } \\
(0-4)\end{array}$ & $\begin{array}{c}\text { Contacting } \\
\quad(0-4)\end{array}$ & $\begin{array}{c}\text { Protesting } \\
\quad(0-4)\end{array}$ \\
\hline Constant & -0.023 & 0.064 & 2.364 & 0.096 & 0.195 \\
\hline Physiological security & $-0.140 * *$ & -0.060 & $-0.517 * * *$ & $-0.152 * * *$ & $-0.195 * * *$ \\
\hline Higher education & $0.253 * * *$ & 0.003 & 0.147 & $0.156^{* *}$ & 0.001 \\
\hline Secure* higher education & -0.044 & -0.046 & -0.403 & 0.023 & 0.016 \\
\hline Born free & -0.016 & $-0.094 * *$ & $-0.652 * * *$ & $-0.127 * * *$ & 0.006 \\
\hline $\begin{array}{l}\text { Born free* secure* } \\
\text { higher education }\end{array}$ & -0.304 & -0.043 & 0.573 & -0.048 & 0.087 \\
\hline Rural & 0.047 & $0.127 * * *$ & 0.106 & $-0.075^{* *}$ & -0.050 \\
\hline Women & $-0.102 * * *$ & $0.098 * *$ & -0.070 & 0.000 & -0.026 \\
\hline News media use & $0.064 * * *$ & $0.077 * * *$ & 0.054 & $0.049 * * *$ & 0.067 \\
\hline Cognitive engagement & $0.176^{* * *}$ & $0.170 * * *$ & $0.447 * * *$ & $0.084 * * *$ & $0.101 * * *$ \\
\hline Multiple $r$ & 0.341 & 0.278 & 0.344 & 0.290 & 0.212 \\
\hline Adjusted $R^{2}$ & 0.112 & 0.073 & 0.114 & 0.080 & 0.045 \\
\hline$n$ & 1624 & 1829 & 1829 & 1829 & 1829 \\
\hline
\end{tabular}

Cells display unstandardized logistic regression coefficients and levels of statistical significance:

$* p<=0.05$,

$* * p<=0.01$,

$* * * p<=0.001$. 
dummy variables with Black as the excluded category. The results can be summarized fairly parsimoniously.

In terms of democratic values, race plays almost no role in differentiating amongst the attitudes of middle-class South Africans (Table 7). In terms of their issue priorities, White respondents are significantly less likely to emphasize basic necessities and more likely to

Table 7. Intra-class racial differences in democratic values (physiologically secure and educated respondents)

\begin{tabular}{lcccc}
\hline & $\begin{array}{c}\text { Demand for } \\
\text { democracy } \\
(0-4)\end{array}$ & $\begin{array}{c}\text { Demand for } \\
\text { democratic institutions } \\
(0-4)\end{array}$ & $\begin{array}{c}\text { Support for free } \\
\text { news media } \\
(0-4)\end{array}$ & $\begin{array}{c}\text { Support for } \\
\text { free association } \\
(0-4)\end{array}$ \\
\hline Constant & 2.526 & 2.464 & 1.808 & 2.46 \\
White & 0.072 & 0.066 & 0.243 & 0.178 \\
Coloured & -0.117 & 0.007 & 0.109 & -0.057 \\
Indian & -0.021 & 0.135 & 0.165 & 0.092 \\
Born free & -0.086 & 0.011 & $-0.288^{* * *}$ & 0.047 \\
Rural & -0.021 & 0.112 & 0.147 & 0.046 \\
Women & 0.061 & -0.023 & 0.133 & -0.108 \\
News media use & $0.077^{* *}$ & 0.033 & $0.155^{* *}$ & 0.064 \\
Cognitive engagement & $0.105^{* *}$ & 0.029 & 0.048 & -0.038 \\
Multiple $r$ & 0.204 & 0.092 & 0.197 & 0.088 \\
Adjusted $R^{2}$ & 0.041 & 0.000 & 0.028 & 0.001 \\
$n$ & 731 & 731 & 731 & 731 \\
\hline
\end{tabular}

Cells display unstandardized ordinary least squares regression coefficients and levels of statistical significance: $* p<=0.05$,

$* * p<=0.01$,

$* * * p<=0.001$.

Table 8. Intra-class racial differences in issue priorities (physiologically secure and educated respondents)

\begin{tabular}{lcccc}
\hline & $\begin{array}{c}\text { Basic } \\
\text { physiological } \\
\text { priorities }\end{array}$ & $\begin{array}{c}\text { Economic } \\
\text { middle-order } \\
\text { priorities }\end{array}$ & $\begin{array}{c}\text { Security } \\
\text { middle order } \\
\text { priorities }\end{array}$ & $\begin{array}{c}\text { Higher-order } \\
\text { priorities }\end{array}$ \\
\hline Constant & 0.633 & 2.065 & -0.913 & -0.795 \\
White & $-0.521^{* *}(0.594)$ & $-0.440(0.644)$ & $0.703^{* * *}(2.019)$ & $0.649^{* * *}(1.913)$ \\
Coloured & $-0.200(0.819)$ & $-0.129(0.879)$ & $0.278(1.320)$ & $0.544^{*}(1.740)$ \\
Indian & $0.328(1.388)$ & $0.468(1.596)$ & $0.273(1.313)$ & $-0.459(0.632)$ \\
Born free & $-0.017(0.983)$ & $-0.104(0.901)$ & $0.251(1.285)$ & $-0.083(0.921)$ \\
Rural & $0.327(1.386)$ & $0.070(1.073)$ & $0.303(0.739)$ & $-0.160(0.852)$ \\
Women & $0.403^{* *(1.496)}$ & $-0.080(0.923)$ & $-0.173(0.841)$ & $-0.193(0.825)$ \\
News media use & $0.013(1.013)$ & $-0.199(0.819)$ & $0.129(1.138)$ & $0.136(1.146)$ \\
Cognitive & $0.058(1.060)$ & $0.414 * * *(1.512)$ & $-0.089(0.915)$ & $-0.157(0.855)$ \\
engagement & & & 0.051 & 0.062 \\
Nagelkerke $R^{2}$ & 0.037 & 0.049 & 713 & 731 \\
$n$ & 731 & 731 & & \\
\hline
\end{tabular}

Cells display unstandardized logistic regression coefficients; levels of statistical significance:

$* p<=0.05$,

$* * p<=0.01$

$* * * p<=0.001 ;$ and odds ratio. 
list issues of crime and security, as well as governance issues of corruption, environment, political rights and democracy. Middle-class Coloured citizens are also more likely to cite these 'higher-order' priorities (Table 8). More consistent racial effects can be seen when we turn to evaluations of government performance. With one exception (White respondents' views of macro-economic management), White, Coloured and Indian middle-class respondents are consistently more negative than middle-class Blacks in terms of their evaluations of government management of the economy, service delivery, and crime and corruption, as well as presidential performance (with the largest differences coming with respect to President Jacob Zuma) (Table 9).

Very large racial differences emerge once we turn to issues of partisanship and voting. As with government performance evaluations, but by a far greater margin, White, Coloured and Indian middle-class respondents are consistently far less likely to identify with the ANC or to vote for it and far more likely to identify with the DA and vote for it. Indeed, the models explaining vote choice in the mock ballot account for 71 and 64 per cent of the variance, with the three racial dummy variables doing almost all of the work. In the most extreme example, while physiologically secure Black respondents were 2.7 times more likely (the odds ratio) to vote for the DA than poorer Black people (Table 4), the odds of a White middle-class respondent voting for the DA are 158 times higher than a Black middle-class respondent (Table 10).

Finally, with a few exceptions, White, Coloured and Indian middle-class respondents are consistently less likely than middle-class Blacks to have taken part in the 2009 election campaign, get involved in community politics, contact public officials or take part in political protest. In the most extreme, but by no means atypical example, in comparison with Black respondents, Whites score a full 1.2 points lower on the 5-point scale of participation in community politics (Table 11).

Table 9. Intra-class racial differences in government performance evaluations (physiologically secure and educated respondents)

\begin{tabular}{|c|c|c|c|c|}
\hline & $\begin{array}{c}\text { Macro-economic } \\
\text { management } \\
(0-4)\end{array}$ & $\begin{array}{l}\text { Service } \\
\text { delivery } \\
(0-4)\end{array}$ & $\begin{array}{l}\text { Crime and } \\
\text { corruption } \\
\quad(0-4)\end{array}$ & $\begin{array}{c}\text { Presidential } \\
\text { performance } \\
\quad(0-4)\end{array}$ \\
\hline Constant & 0.837 & 1.921 & 1.373 & 2.168 \\
\hline White & -0.101 & $-0.272 * * *$ & $-0.390 * * *$ & $-0.679 * * *$ \\
\hline Coloured & $-0.273^{* *}$ & $-0.255^{* *}$ & $-0.355^{* * *}$ & $-0.697 * * *$ \\
\hline Indian & $-0.593 * * *$ & $-0.468 * * *$ & $-0.881 * * *$ & $-1.002 * * *$ \\
\hline Born free & 0.131 & 0.084 & -0.028 & 0.110 \\
\hline Rural & $0.226^{*}$ & -0.018 & 0.224 & 0.133 \\
\hline Women & 0.013 & -0.047 & 0.009 & -0.018 \\
\hline News media use & $0.064 *$ & 0.026 & 0.048 & 0.071 \\
\hline $\begin{array}{l}\text { Cognitive } \\
\text { engagement }\end{array}$ & $0.121 * *$ & 0.034 & 0.024 & 0.089 \\
\hline Multiple $r$ & 0.263 & 0.214 & 0.228 & 0.331 \\
\hline Adjusted $R^{2}$ & 0.059 & 0.035 & 0.041 & 0.091 \\
\hline$n$ & 731 & 731 & 731 & 731 \\
\hline
\end{tabular}

Cells display unstandardized ordinary least squares regression coefficients and levels of statistical significance:

$* p<=0.05$,

$* * p<=0.01$,

$* * * p<=0.001$. 


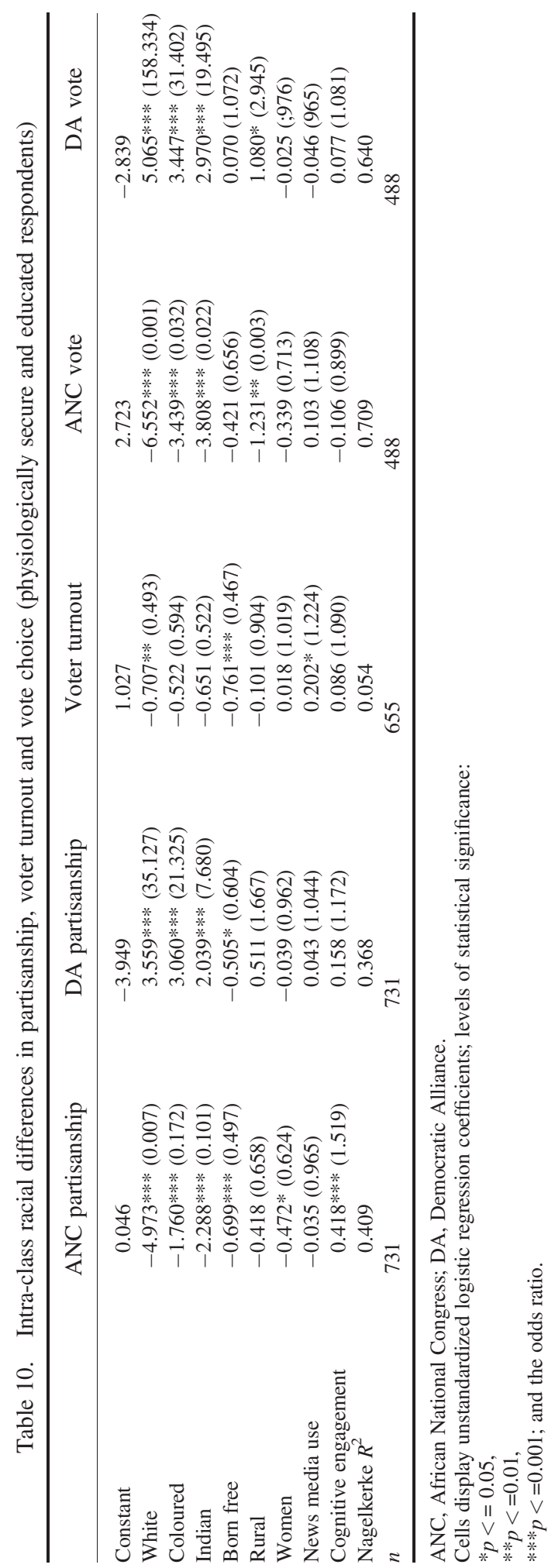


Table 11. Intra-class racial differences in political participation (physiologically secure and educated respondents)

\begin{tabular}{lccccc}
\hline & $\begin{array}{c}\text { Campaigning } \\
(0-4)\end{array}$ & $\begin{array}{c}\text { Joining } \\
(0-4)\end{array}$ & $\begin{array}{c}\text { Communing } \\
(0-4)\end{array}$ & $\begin{array}{c}\text { Contacting } \\
(0-4)\end{array}$ & $\begin{array}{c}\text { Protesting } \\
(0-4)\end{array}$ \\
\hline Constant & 0.112 & 0.130 & 1.332 & 0.008 & 0.175 \\
White & $-0.310^{* * *}$ & -0.061 & $-1.231^{* * *}$ & $-0.278^{* * *}$ & $-0.207^{* * *}$ \\
Coloured & $-0.207^{* * *}$ & -0.115 & $-1.067^{* * *}$ & $-0.172^{* * * *}$ & $-0.164^{* *}$ \\
Indian & $-0.364^{* * *}$ & 0.079 & $-1.067^{* *}$ & $-0.207 * *$ & -0.155 \\
Born free & -0.038 & $-0.110^{*}$ & $-0.304^{* *}$ & $-0.114^{*}$ & -0.001 \\
Rural & $0.194^{* *}$ & 0.121 & $0.470^{* * *}$ & -0.029 & $0.199^{* *}$ \\
Women & $-0.084^{*}$ & $0.123^{* * *}$ & -0.007 & -0.027 & -0.076 \\
News media use & 0.023 & $0.069^{* *}$ & $0.148^{* * *}$ & $0.051^{* * *}$ & $0.041^{*}$ \\
Cognitive engagement & $0.155^{* * *}$ & $0.120^{* * *}$ & $0.501^{* * *}$ & $0.100^{* * *}$ & $0.082^{* * *}$ \\
Multiple $r$ & 0.421 & 0.251 & 0.485 & 0.379 & 0.294 \\
Adjusted $R^{2}$ & 0.167 & 0.053 & 0.227 & 0.134 & 0.076 \\
$n$ & 655 & 731 & 731 & 731 & 731 \\
\hline
\end{tabular}

Cells display unstandardized logistic regression coefficients and levels of statistical significance:

$* p<=0.05$

$* * p<=0.01$

$* * * p<=0.001$

\section{CONCLUSION}

Whether measured by income, occupation, physiological security or higher education, a sizable proportion of Black South Africans can now be called 'middle class'. The political consequences of this development, however, remain limited. Since the end of apartheid, South Africans have exhibited relatively lukewarm support for their new democratic regime. And the 'born free' post-apartheid generation is even less strongly committed to democracy than their parents or grandparents (Mattes, 2012). Given the theoretical arguments reviewed at the beginning of this paper, the emerging Black middle class might have been expected to provide an important constituency that would defend democratic institutions against encroachment. But as of 2011, Black South Africans who enjoy physiological security or have had access to higher education do not exhibit sharply different values about democracy, than their poorer compatriots. Indeed, Black middle-class respondents are more likely to 'exit' the democratic process rather than 'voice' their concerns by voting, taking part in election campaigns, contacting elected representatives and government officials or joining with others to achieve political outcomes, whether through convention or unconventional forms of collective action.

Yet there is evidence that the Black middle class' preferences for government action are beginning to diverge from poorer and less well-educated Blacks. As the theory of post-materialism (Inglehart \& Abramson, 1995; Inglehart \& Welzel, 2005) would predict, middle-class Black people are more likely to want the government to secure higher-order needs of good governance and self-expression and less likely to prioritize securing basic needs. And while diverging material interests and differing value priorities have not yet resulted in more critical evaluations of government performance, there are signs that they are leading to differences in voting behaviour. Black middle-class respondents are less likely to identify with the dominant, ruling ANC and more likely to say they would vote for the liberal, historically 'White' DA in a future election. Thus, there is little reason to conclude that, by helping to create a new Black middle class, the governing ANC has bought itself a new, growing constituency whose loyalty might sustain it if or when it begins to lose support amongst the homeless and the unemployed. 
Yet while many have hoped that the rise of the Black middle class will form a new, cross-cutting cleavage that unites people of similar classes across the old apartheid divides of race and ethnicity, racial differences between middle-class Blacks, on one hand, and middle-class White, Coloured and Indian South Africans, on the other, are still substantial. Even though the income gap between Blacks and Whites is now smaller than amongst Black South Africans (Bhorat \& Van Der Westhuizen, 2010; Leibbrandt et al., 2010), there are still far greater racial differences in political participation and to a somewhat lesser extent political preferences and performance evaluations amongst the middle class than between middle-class and poorer Blacks. At least for now, the rise of the Black middle class does not portend a new non-racial dimension in South African politics. Middle-class South Africans are still far more likely to define their interests based on the deep history of apartheid rather than their current material status. In other words, class is still a nascent factor in South African politics.

\section{REFERENCES}

Acemoglu D, Johnson S, Robinson J, Yard P. 2008. Income and Democracy. American Economic Review 98(3): 808-842.

Bannerjee A, Duflo E. 2008. What Is Middle Class About Middle Classes Around the World? Journal of Economic Perspectives 22(2): 3-28.

Bhorat H, Van Der Westhuizen C. 2010. Poverty, inequality and the nature of economic growth in South Africa. In Testing Democracy Which Way Is South Africa Going?, Misra-Dexter N, February J (eds). IDASA: Cape Town.

Bratton M, Mattes R, Gyimah-Boadi E. 2005. Public Opinion, Democracy and Market Reform in Africa. Cambridge: Cambridge University Press.

Budlender D. 2000. Earnings inequality in South Africa, 1995-1998. In Measuring Poverty in South Africa. Statistics South Africa: Pretoria.

Dalton R. 2013. Citizen Politics: Public Opinion and Political Behavior in Four Industrial Democracies, 6th edition. Sage: Washington DC.

Donnelly L. 2013. SA bears the burdens of a better life. Mail and Guardian, 13 to 19 December: 3. Epstein D, Bates R, Goldstone J, Krisenson I, O'Halloran S. 2006. Democratic Transitions. American Journal of Political Science 50(3): 551-569.

Everatt D. 2013. The South African middle class. In Rising Middle Classes in India, Brazil and South Africa: What Is Happening and What Are the Implications? Bernstein A (ed.). Centre for Development and Enterprise: Johannesburg; 33-35.

Everatt D. 2014. Gauteng and the Arrival of Uncertainty. The Journal of the Helen Suzman Fondation 74: 10-18.

Feree K. 2011. Framing the Race in South Africa: The Political Orogins of Racial-Census Elections. Cambridge University Press: Cambridge.

Halperin M, Siegle J, Weinstein M. 2005. The Democracy Advantage: How Democracies Promote Prosperity and Peace. Routledge: New York.

Hirschmann A. 1970. Exit, Voice and Loyalty: Responses to Decline in Firms, Organizations and States. Harvard University Press: Cambridge.

Huntington S. 1991. The Third Wave: Democratization in the Late 20th Century. University of Oklahoma Press: Norman, OK.

Inglehart R, Abramson P. 1995. Value Change in Global Perspective. University of Michigan Press: Ann Arbor, Mi. 
Inglehart R, Welzel C. 2005. Modernization, Cultural Change and Democracy: The Human Development Sequence. Cambridge University Press: Cambridge.

Inkeles A. 1969. Making Men Modern: On the Causes and Consequences of Individual Change in Six Developing Countries. American Journal of Sociology 75(2): 208-225.

Kane-Berman J. 2014. ANC's balance sheet includes many successes with its failures. Business Day 27 January.

Kotze H, du Toit P, Steenkamp CL, Burger R, Van Der Berg S. 2013. The emergent South African middle class. Research on Socio-Economic Policy, University of Stellenbosch (http://resep.sun. ac.za/wp-content/uploads/2013/10/The-emergent-SA-middle-class_.pdf).

Leibbrandt M, Woolard I, Finn A, Argent J. 2010. Trends in South African income distribution and poverty since the fall of apartheid. OECD Social, Employment and Migration Working Papers, no. 101. OECD Publishing: Paris.

Lipset SM. 1959. Some Social Requisites of Democracy: Economic Development and Political Legitimacy. American Political Science Review 53(1): 69-105.

Lufeka CL, Mabila MB, Aissa MS. 2011. The middle of the pyramid: dynamics of the middle class in Africa. African Development Bank, Market Brief. 20 April 2011.

Mannheim K. 1972. The problem of generations. In Karl Mannheim: Essays. Kecksemeti P (ed). Routledge: London; 276-322.

Marx K, Engels F. 1992. The Communist Manifesto, Translated by Samuel Moore. Oxford University Press: Oxford.

Maslow A. 1954. Motivation and Personality. Harper: New York.

Mattes R. 2008. The Material and Political Bases of Lived Poverty in Africa: Insights From the Afrobarometer. In Barometers of Quality of Life Around the Globe: How Are We Doing?, Møller V, Huschka D, Michalos A (eds.). Springer Science Business Media B.V.

Mattes R, Mozaffar S. 2011. Education, Legislators and Legislatures in Africa. Higher Education Research and Advocacy Network in Africa Paper. Cape Town: Centre for Higher Education Transformation.

Mattes R. 2012. The 'Born Frees': The Prospects for Generational Change in Post-Apartheid South Africa. Australian Journal of Political Science 47(1): 133-153.

McAravey C, Burger R, Van der Berg S. 2013. The Capability Threshold: Re-examining the Definition of the Middle Class in an Unequal Developing Country. Paper Presented to Human Development and Capability Association Annual Conference. Managua, Nicaragua. 9-12 September.

Moore B. 1966. The Social Origins of Dictatorship and Democracy. Beacon Press: Boston.

Netzhitenzhe J. 2014. 'Radical' Change Is Out Collective Responsibility. Mail \& Guardian June 27 to July 3: 25-28.

Norris P. 2003. Democratic Phoenix: Reinventing Political Activism. Cambridge University Press: Cambridge.

Norris P. 2008. Driving Democracy: Do Power-Sharing Institutions Work? Cambridge University Press: Cambridge.

Presidency, Republic of South Africa. 2014. Twenty Year Review: South Africa 1994-2014. The Presidency, Republic of South Africa: Pretoria.

Przeworski A, Alvarez M, Cheibub JA, Limongi F. 2000. Democracy and Development: Political Institutions and Well-being in the World, 1950-1990. Cambridge University Press: Cambridge.

Seekings J, Nattrass N. 2005. Class, Race and Inequality in South Africa. Yale University Press: New Haven.

Seekings J, Nattrass N. 2014. The South African class structure after apartheid. CSSR Working

Papers. Centre for Social Science Research, University of Cape Town: Cape Town, forthcoming.

Southall R. 2012. The ANC: party vanguard of the Black middle class?. In One Hundred Years of the ANC: Debating Liberation Histories Today, Lissoni A, Soske J, Erlank N, Nieftagodien N, Badsha O (eds). Wits University Press: Johannesburg; 325-346. 
Southall R. 2014. The Black Middle Class and Democracy in South Africa. Journal of Modern African Studies 52(34): 647-670.

Teorell J. 2010. Determinants of Democratization: Explaining Regime Change in the World, 1972-2006. Cambridge University Press: Cambridge.

Van Der Berg S. 2010. Current poverty and income distribution in the context of South African history. Stellenbosch Economic Working Papers, no. 22/10). Bureau for Economic Research: University of Stellenbosch.

Van der Berg S, Louw M, du Toit L. 2007. Poverty trends since the transition: what we know. Stellenbosch Economic Working Papers, no. 19/09. Bureau for Economic Research, University of Stellenbosch.

Visagie J, Posel D. 2011. A reconsideration of what and who is middle class in South Africa. Working Paper 249 (October).

Weber M. 1958. Class, status and party. In From Max Weber: Essays in Sociology, Gerth H, Mills CW (eds). Oxford University Press: Oxford.

Whiteford A, Van Seventer D. 1999. Winners and Losers: South Africa's Changing Income Distribution in the 1990s. WEFA: Johannesburg.

\title{
APPENDIX
}

\section{QUESTION WORDING FOR INDEPENDENT VARIABLES}

\author{
Table 1. Correlates of class
}

\footnotetext{
Physiological security

Over the past year, how often, if ever, have you or anyone in your family:

Gone without enough food to eat?

Gone without enough clean water for home use?

Gone without medicines or medical treatment?

Gone without enough fuel to cook your food?

( $1=$ never, $0=$ just once or twice, several times, many times, always, do not know)

Post-secondary Education

What is the highest level of education you have completed?

$[1=$ post-secondary qualifications other than university (e.g. a diploma or a degree from a polytechnic or a college), some university, university completed, post-graduate; $0=$ no formal schooling, informal schooling only, some primary schooling, primary school completed, some secondary school, secondary school completed] News media use

How often do you get news from the following sources:

Radio

Television

Newspapers

Internet

$(0=$ never, do not know, $1=$ less than once a month, $2=$ a few times a month, $3=$ a few times a week, $4=$ every day $)$ Factor analysis extracted a single unrotated factor (Eigenvalue $=1.70$ ), which explains $42.4 \%$ of the common variance. Index reliability (Cronbach's alpha $=0.54)$ is low but above minimum standards for cut off $(n=2400)$. Cognitive engagement

How interested would you say you are in public affairs?

$(0=$ not at all interested/do not know, $1=$ not very interested, $2=$ somewhat interested, $3=$ very interested $)$

When you get together with your friends or family, would you say you discuss political matters?

$(0=$ never/do not know, $1.5=$ occasionally, $3=$ frequently $)$

The items measuring political interest and political discussion are sufficiently correlated (Pearson's $r=0.45$ ) and reliable (Cronbach's alpha $=0.62)$ to warrant the creation of a two-item average of cognitive engagement $(n=2400)$.
} 
Table 2. Consequences of class for democratic values

Demand for democracy

Which of these three statements is closest to your own opinion?

Statement 1: Democracy is preferable to any other kind of government.

Statement 2: In some circumstances, a non-democratic government can be preferable.

Statement 3: For someone like me, it does not matter what kind of government we have

Do not know

$(0=$ statement $3 /$ do not know, 2 = statement 2 , 4 = statement 1$)$

There are many ways to govern a country. Would you disapprove or approve of the following alternatives?

Only one political party is allowed to stand for election and hold office.

The army comes in to govern the country.

Elections and Parliament are abolished so that the President can decide everything.

$(0=$ strongly approve, 1 = approve, $2=$ do not know, $3=$ disapprove, $4=$ strongly disapprove $)$

Factor analysis extracted a single unrotated factor (Eigenvalue $=2.05$ ), which explains $51.1 \%$ of the common

variance. Index reliability (Cronbach's alpha $=0.67)$ is acceptable $(n=2400)$.

Demand for democratic institutions

Statement 1: We should choose our leaders in this country through regular, open and honest elections.

Statement 2: Because elections sometimes produce bad results, we should adopt other methods for choosing this country's leaders.

Statement 1: Parliament should ensure that the President explains to it on a regular basis how his government spends taxpayers' money.

Statement 2: The President should be able to devote his full attention to developing the country rather than wasting time justifying his actions.

Statement 1: The news media should constantly investigate and report on government mistakes and corruption.

Statement 2: Too much reporting on negative events, like government mistakes and corruption, only harms the country.

Statement 1: Members of the Parliament represent the people; therefore, they should make laws for this country, even if the President does not agree.

Statement 2: Because the President represents all of us, he should pass laws without worrying about what the Parliament thinks.

Statement 1: The constitution should limit the President to serving a maximum of two terms in office.

Statement 2: There should be no constitutional limit on how long the President can serve.

$(0=$ agree very strongly with statement $2,1=$ agree with statement $2,2=$ agree with neither/do not know,

$3=$ agree with statement $1,4=$ agree very strongly with statement 1 )

Factor analysis extracted a single unrotated factor (Eigenvalue $=1.74$ ), which explains $34.8 \%$ of the common variance. Index reliability (Cronbach's alpha $=0.53)$ is low but above minimum standards for cut off $(n=2400)$. Support for free association

Which of the following statements is closest to your view? Choose statement 1 or statement 2.

Statement 1: Government should be able to ban any organization that goes against its policies.

Statement 2: We should be able to join any organization, whether or not the government approves of it.

$(0=$ agree very strongly with statement $1,1=$ agree with statement $1,2=$ agree with neither/do not know,

$3=$ agree with statement 2, $4=$ agree very strongly with statement 2 )

Support for free news media

Which of the following statements is closest to your view? Choose statement 1 or statement 2.

Statement 1: The media should have the right to publish any views and ideas without government control.

Statement 2: The government should have the right to prevent the media from publishing things that it considers harmful to society.

$(0=$ agree very strongly with statement $2,1=$ agree with statement $2,2=$ agree with neither/do not know,

$3=$ agree with statement $1,4=$ agree very strongly with statement 1 )

Table 3. Consequences of class for issue priorities

Basic physiological priorities

In your opinion, what are the most important problems facing this country that the government should address?

(Continues) 


\section{Table 3. (Continued)}

(1 = poverty/destitution, farming/agriculture, food shortage/famine, drought, land, housing, electricity, water supply, orphans/street children/homeless children, health, aids, sickness/disease, agricultural marketing; $0=$ all other answers)

Economic security middle-order priorities

In your opinion, what are the most important problems facing this country that the government should address? ( 1 = management of the economy, wages, incomes, salaries, unemployment, rates, taxes, loans, credit, transportation, communications, infrastructure, roads, education, services (others); $0=$ all other answers)

Physical safety middle-order priorities

In your opinion, what are the most important problems facing this country that the government should address? ( 1 = crime, security, political violence, political instability, political divisions, ethnic tensions, war (international), civil war; $0=$ all other answers)

Higher-order priorities

In your opinion, what are the most important problems facing this country that the government should address? ( 1 = corruption, discrimination/inequality, gender issues/women's rights, democracy/political rights; $0=$ all other answers)

Note: The theory of measurement underlying these indices is not based on the concept of covariance. The response categories were open-ended. And while the number of problems mentioned by the total sample is very large, each respondent was able to mention only three. Thus, I do not necessarily expect those who choose one type of problem will necessarily choose other problems of the same conceptual area. What is desired is a simple indication of whether a respondent mentioned a type of problem as one of the three response.

\section{Table 4. Consequences of class for government performance evaluations}

\section{Macro-economic management}

How well or badly would you say the current government is handling the following matters, or haven't you heard enough to say?

Managing the economy

Creating jobs

Keeping prices down

Narrowing gaps between the rich and the poor

( 0 = very badly, 1 = badly, $2=$ do not know/haven't heard enough, $3=$ well, 4 = very well $)$

Factor analysis extracted a single unrotated factor (Eigenvalue $=2.41$ ), which explains $60.3 \%$ of the common

variance. Index reliability (Cronbach's alpha $=0.78)$ is high $(n=2400)$.

Service delivery

How well or badly would you say the current government is handling the following matters, or haven't you heard enough to say?

Improving the living standards of the poor

Improving basic health services

Addressing educational needs

Providing water and sanitation services

Ensuring everyone has enough to eat

Combating HIV/AIDS

Maintaining roads and bridges

Providing a reliable supply of electricity

$(0=$ very badly, $1=$ badly, $2=$ do not know/have not heard enough, $3=$ well, $4=$ very well $)$

Factor analysis extracted a single unrotated factor (Eigenvalue $=3.66$ ), which explains $45.8 \%$ of the common

variance. Index reliability (Cronbach's alpha $=0.85)$ is high $(n=2400)$.

Controlling crime and corruption

How well or badly would you say the current government is handling the following matters, or haven't you heard enough to say?

Reducing crime

Fighting corruption in government 


\section{Table 4. (Continued)}

( 0 = very badly, 1 = badly, $2=$ do not know/haven't heard enough, $3=$ well, $4=$ very well $)$

The items measuring approval of crime and corruption are sufficiently correlated (Pearson's $r=0.49$ ) and reliable (Cronbach's alpha $=0.66$ ) to warrant the creation of a two-item average of controlling crime and corruption $(n=2400)$.

Presidential performance

Do you approve or disapprove of the way that President Jacob Zuma the following people have performed their jobs over the past 12 months, or haven't you heard enough about them to say?

$(0=$ very badly, 1 = badly, 2 = do not know/haven't heard enough, $3=$ well, $4=$ very well $)$

Table 5. Consequences of class for partisanship, turnout and vote choice

\section{Partisanship}

Do you feel close to any particular political party?

(1=yes; $0=$ no, do not know)

ANC partisanship

Do you feel close to any particular political party? If yes, which party is that?

( 1 = African National Congress; $0=$ all other parties, do not feel close to a party, do not know)

Voter turnout

With regard to the most recent national election in 2009, which statement is true for you?

( 1 = you voted in the elections; $0=$ you were not registered or you were too young to vote, you decided not to vote, you could not find the polling station, you were prevented from voting, you did not have time to vote, you did not vote because you could not find your name in the voters' register, you did not vote for some other reason, do not know)

ANC vote

If a national election were held tomorrow, which party would you vote for?

$(1=$ African National Congress $0=$ all other parties, would not vote, do not know $)$

Table 6. Consequences of class for political participation

Campaigning

Thinking about the last national election in [20xx], did you:

Attend a campaign, a meeting or a rally?

Try to persuade others to vote for a certain presidential or legislative candidate or political party?

Work for a candidate or party?

$(0=$ no, do not know; $1=$ yes $)$

Factor analysis extracted a single unrotated factor (Eigenvalue $=1.82$ ), which explains $60.6 \%$ of the common variance. Index reliability (Cronbach's alpha $=0.67)$ is acceptable $(n=2400)$.

Joining

Now, I am going to read out a list of groups that people join or attend. For each one, could you tell me whether you are an official leader, an active member, an inactive member, or not a member?

A religious group that meets outside of regular worship services

Some other voluntary association or community group

$(0=$ not a member, do not know; 1 = inactive member; $2=$ active member; $3=$ official leader $)$

The items measuring membership in religious groups and voluntary associations are sufficiently correlated

(Pearson's $r=0.45$ ) and reliable (Cronbach's alpha $=0.61$ ) to warrant the creation of a two-item average of joining $(n=2400)$.

\section{Communing}

Here is a list of actions that people sometimes take as citizens. For each of these, please tell me whether you, personally, have done any of these things during the past year.

Attended a community meeting

Got together with others to raise an issue

$(0=$ no, would never do this; $1=$ no, would if had the chance; $2=$ yes, once or twice; $3=$ yes, several times; $4=$ yes, often) 


\section{Table 6. (Continued)}

The items measuring community meetings and raising issues are sufficiently correlated (Pearson's $r=0.70)$ and reliable (Cronbach's alpha $=82)$ to warrant the creation of a two-item average of communing $(n=2400)$.

\section{Contacting}

During the past year, how often have you contacted any of the following persons about some important problem or to give them your views?

A local government councillor

A member of Parliament

An official of a government agency

A political party official

$(0=$ never, do not know; $1=$ only once; $2=$ a few times; $3=$ often $)$

Factor analysis extracted a single unrotated factor (Eigenvalue $=2.64$ ), which explains $66.1 \%$ of the common variance. Index reliability (Cronbach's alpha $=0.69)$ is acceptable $(n=2400)$.

\section{Protesting}

Here is a list of actions that people sometimes take as citizens. For each of these, please tell me whether you, personally, have done any of these things during the past year.

Attended a demonstration or a protest march

Used force or violence for a political cause

$(0=$ no, would never do this; $1=$ no, would if had the chance; $2=y e s$, once or twice; $3=$ yes, several times; $4=$ yes, often)

Factor analysis extracted a single unrotated factor (Eigenvalue $=2.00$ ), which explains $66.8 \%$ of the common variance. Index reliability (Cronbach's alpha $=0.73)$ is high $(n=2400)$. 